\title{
Russula graminea, a new green species from Fennoscandia
}

\author{
JUKKA VAURAS, JUHANI RUOTSALAINEN and KARE LIIMATAINEN
}

VAURAS, J., RUOTSALAINEN, J. \& LIIMATAINEN, K. 2012: Russula graminea, a new green species from Fennoscandia. - Karstenia 52:51-57. HELSINKI. ISSN 04533402 .

Russula graminea, a new species occurring with Picea abies, is described and illustrated. It is known from Finland, Sweden and Norway, from southern to northern boreal zone. This rare species is distinct by the following characters: fruit bodies fairly large and robust, pileus markedly olive-green, often with yellow spots, lamellae pale yellow, mild to acrid when young, later mild, stipe white, and spores in mass ochre (IIIa-IVa).

Key words: Russulales, Picea abies, Russula graminea, Fennoscandia, taxonomy

Jukka Vauras, Biological Collections of Abo Akademi University, Herbarium, FI-20014 University of Turku, Finland; e-mail: jukka.vauras@utu.fi

Juhani Ruotsalainen, Metsätie 12 A 4, FI-71310 Vehmersalmi, Finland; e-mail: juhani. ruotsalainen@pp.inet.fi

Kare Liimatainen, Plant Biology, Department of Biosciences, P.O. Box 65, FI-00014 University of Helsinki, Finland; e-mail: kare.liimatainen@helsinki.fi

\section{Introduction}

In earlier papers we have dealt with some northern species of Russula, characterized by green pileus, or at least often green shades, namely Russula olivina Ruots. \& Vauras and R. postiana Romell (Ruotsalainen \& Vauras 1990), R. pubescens A.Blytt (Ruotsalainen \& Vauras 1991), R. olivobrunnea Ruots. \& Vauras and $R$. groenlandica Ruots. \& Vauras (Ruotsalainen \& Vauras 1994), $R$. violaceoincarnata Knudsen \& T.Borgen (Ruotsalainen \& Vauras 1995), $R$. fulvograminea Ruots., Sarnari \& Vauras (Ruotsalainen, Sarnari \& Vauras 1997)). For a longer time we have been aware of a new species, which is described here as Russula graminea, honouring the provisional name used by Tauno Ulvinen (Herbarium of Oulu University, Finland) for his collection from the type locality in 1977 together with Risto Tuomikoski and Mauri
Korhonen. Recently, the species was included in Funga Nordica (Knudsen et al. 2012). It has also been presented in the book of Marstad (2004).

\section{Material and methods}

The colours of fresh specimens were compared with those in Küppers (1981). Spore masses from spore prints were placed between microscope slides and colours were determined as Romagnesi's codes against the colour chart prepared by Christian Dagron. The measurements of the spores were made excluding ornamentation, and basidia lengths excluding sterigmata. The spores were measured in Melzer's reagent, other elements in $10 \%$ ammoniumhydroxide. The averages of the spores and basidia are given as underlined, and $5 \%$ from each end of their range in parentheses.

Molecular analyses. DNA was extracted from a few milligrams of dried material (a piece of lamella) with the $\mathrm{Nu}$ cleoSpin plant kit (Macherey-Nagel, Düren, Germany). Primers ITS 1F and ITS 4 (White et al. 1990; Gardes \& 
Bruns 1993) were used to amplify ITS regions. The same primer pairs were used in direct sequencing. PCR amplification and sequencing followed Niskanen et al. (2009). Sequences were assembled and edited with Sequencher 4.1 (Gene Codes, Ann Arbor, Mich., USA). A total of three new ITS sequences of $R$. graminea were produced for this study.

\section{Russula graminea Ruots., H.Unger \&}

Vauras, sp. nova - Figs. 1-4

MycoBank no.: MB 802595

Species media vel grandis, robusta. Pileo 4-15 $\mathrm{cm}$ lato, pulchre viride, saepe cum maculis viridi-flavis, raro centro rufo-brunneo. Lamellis cremeis, dein subflavis, sapore potius acri, aetate miti. Stipite 6-20 cm longo, 1.5-4 cm crasso, albo, saepe subclavato. Carne alba, odore indistincto, sapore miti. Sporis in cumulo ochraceis, IIIa-IVa in codice Romagnesii, subglobosis, (8.3-)8.5-10.5(-11.0) × (7.0-)7.3-9.1(-9.5) um,ornamentis nonnihil reticulatis, verrucis obtusis usque ad $1.5 \mu \mathrm{m}$ altis, amyloideis. Basidiis 4-sporigeriis. Epicute pilis obtusis, 3-6 dermatocystidiis cylindratis vel subclavaeformibus intermixtis, 4-11 $\mu$ m latis. Habitatio: cum Piceis in silvis adultis, saepe in Sphagno.

Typus: Finland. Koillismaa. Kuusamo, Iivaara mountain, E slope, Isokorpi, mature fairly rich brookside forest with Picea abies and scattered Betula pubescens and Alnus incana, Vaccinium myrtillus abundant, Grid $27^{\circ} \mathrm{E}$ : 7303:623, alt. ca $350 \mathrm{~m}$ a.s.1., 19.VIII.1997 Ruotsalainen 4372F (KUO - holotypus; G, M, MICH, O, S, TUR-A - isotypi).

Etymology: graminea (Latin) refers to the green pileus of the species.

Pileus $4-15 \mathrm{~cm}$ in diam, at first convex, later expanded and depressed, when young and moist greenish yellow, soon bright olive green, often with yellow areas, exceptionally mixed with red to wine-red, centre green, greenish-yellow (S20Y90M00, S20Y99M00) to brown-green (S40Y80M10, S40Y60M10), at margin green (Y80M20C40, Y80M20C30) to pale yellowishgreen (S20C00Y60), blunt, smooth for a long time, later slightly sulcate; surface when moist viscid, when dry mat, not pruinose, uneven, ca half of the pileipellis peeling. Lamellae up to
$22 \mathrm{~mm}$ broad, at first cream white, later creamyellow to pale yellow, with some bifurcations and some lamellulae. Stipe 6-20 × 1.5-4 cm, subclavate, longitudinally rugose, not pruinose, spongy inside, later hollow; at first white, later somewhat greyish and with brown patches at base. Context white, under pileipellis pale greyish green. Odour indistinct. Taste mild in context, fairly acrid to mild in young lamellae, later mild. Spores in mass ochre (Romagnesi IIIa-IVa), $(8.3-) 8.5-9.4-10.5(-11.0) \quad \times \quad(7.0-) 7.3-8.1-$ 9.1(-9.5) $\mu \mathrm{m}$, total range of mean values 8.9-9.8 $\times 7.6-8.6 \mu \mathrm{m}, \mathrm{Q}=1.1-1.16-1.2(-1.3)$, total range of mean $Q$ values 1.14-1.19 (120 spores from 6 collections); subglobose, amyloid, with partial reticulum, warts up to $1.5 \mu \mathrm{m}$ high, blunt to aculeate, plage amyloid. Basidia 39-48-56 $\times$ 12-14-16 $\mu \mathrm{m}(\mathrm{n}=31)$, clavate, 4-spored. $\mathrm{Hy}$ menial cystidia $10-15 \mu \mathrm{m}$ broad, blunt to appendiculate. Pileipellis: apical cells 3-6 $\mu \mathrm{m}$ broad, cylindrical or tapering to apex, some with knobs, dermatocystidia 4-11 $\mu \mathrm{m}$ broad, 1-3 -septate, cylindrical to subclavate, without encrusted elements.

\section{Distribution, ecology and phenology}

Russula graminea has a wide distribution in Fennoscandia. In Finland it has a north-oriented distribution with occurrences mainly in middle and northern boreal zone. In Sweden the species has been collected only at the coast of Gulf of Bothnia, from southern and middle boreal zone, with several localities in Ångermanland. In Norway the southernmost localities are close to the limit of the hemiboreal (boreonemoral) zone.

$R$. graminea grows in fairly old forests of Picea abies, very often on slopes of hills, in paludified brooksides, in or close to Sphagnum. The species seems to be somewhat, but not strongly exacting. In the type locality, at the type site, following plants were listed growing near $R$. graminea:

Fig. 1 (Right up). Russula graminea, Paltamo, Saukkovaara, 24.VIII.2011 Ruotsalainen \& Vauras $28360 F$ (TUR-A). - Photo: J. Ruotsalainen.

Fig. 2 (Right down). Russula graminea, Posio, Noukavaara, 15.VIII.2010 Calledda et al. (TUR-A). - Photo: F. Calledda. 

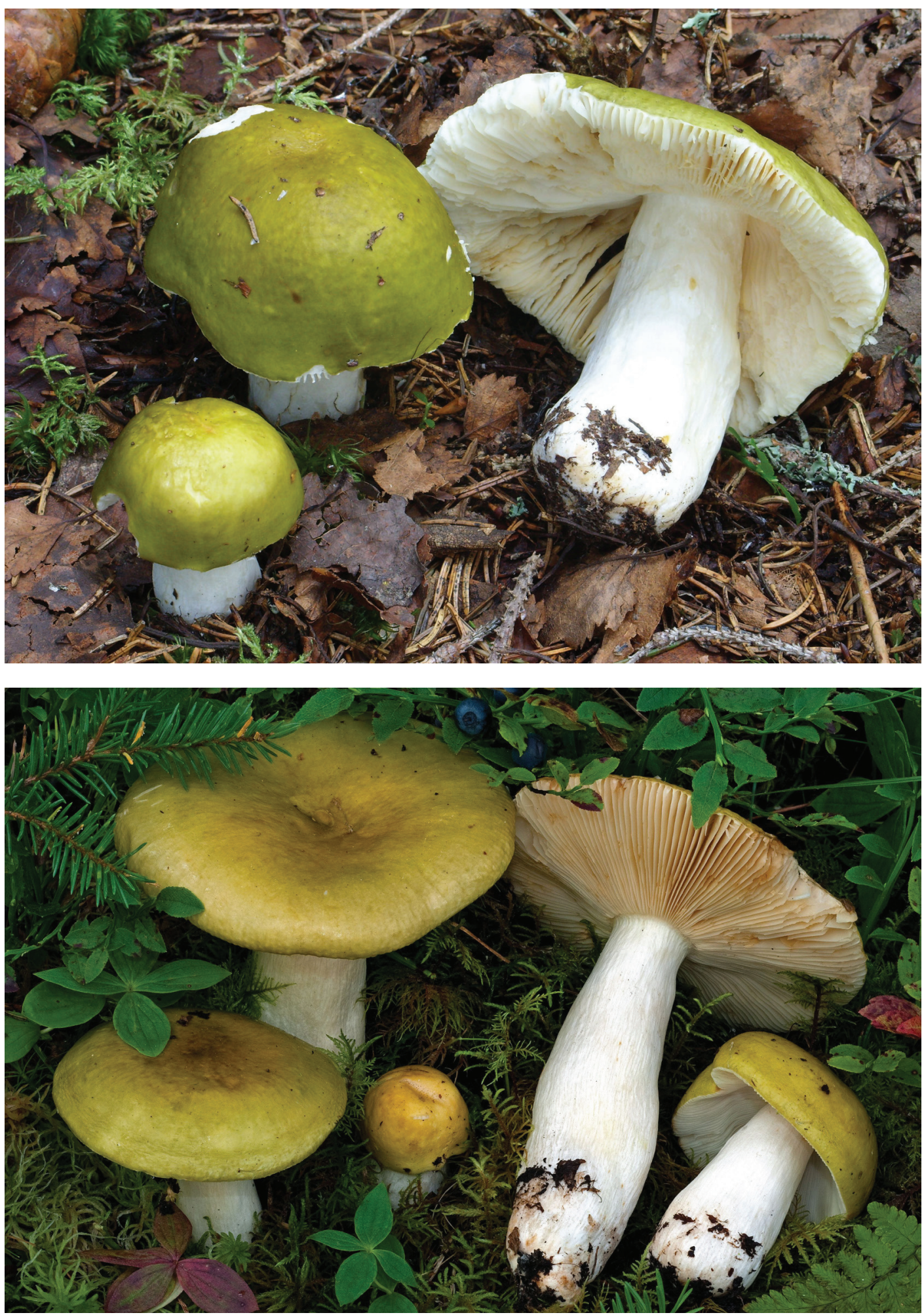


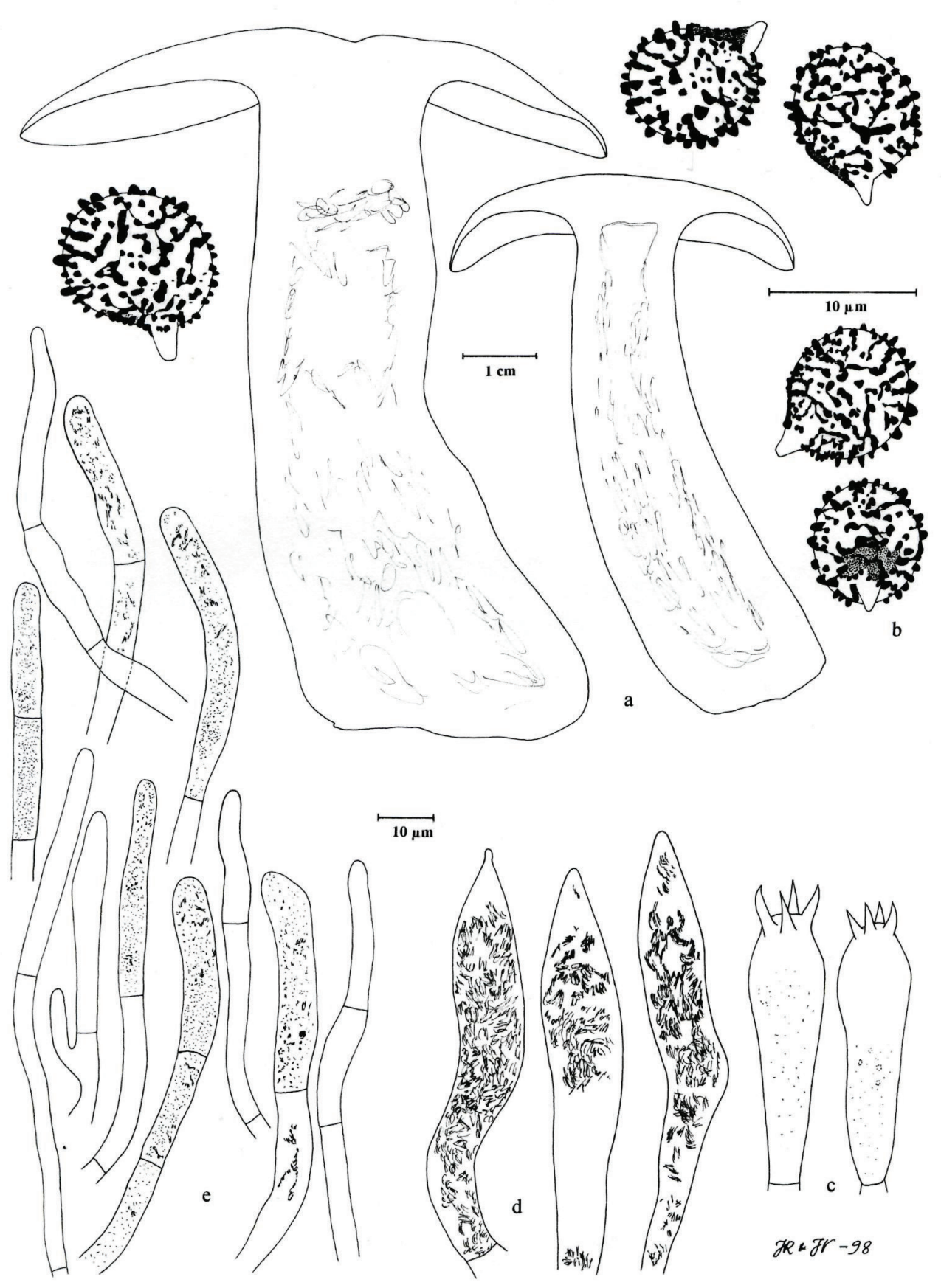

Fig. 3. Holotype of Russula graminea. Cross-sections of fruit bodies (a) and microscopical characters $(b=$ spores, $\mathrm{c}=$ basidia, $\mathrm{d}=$ hymenial cystidia, $\mathrm{e}=$ elements of pileipellis). 


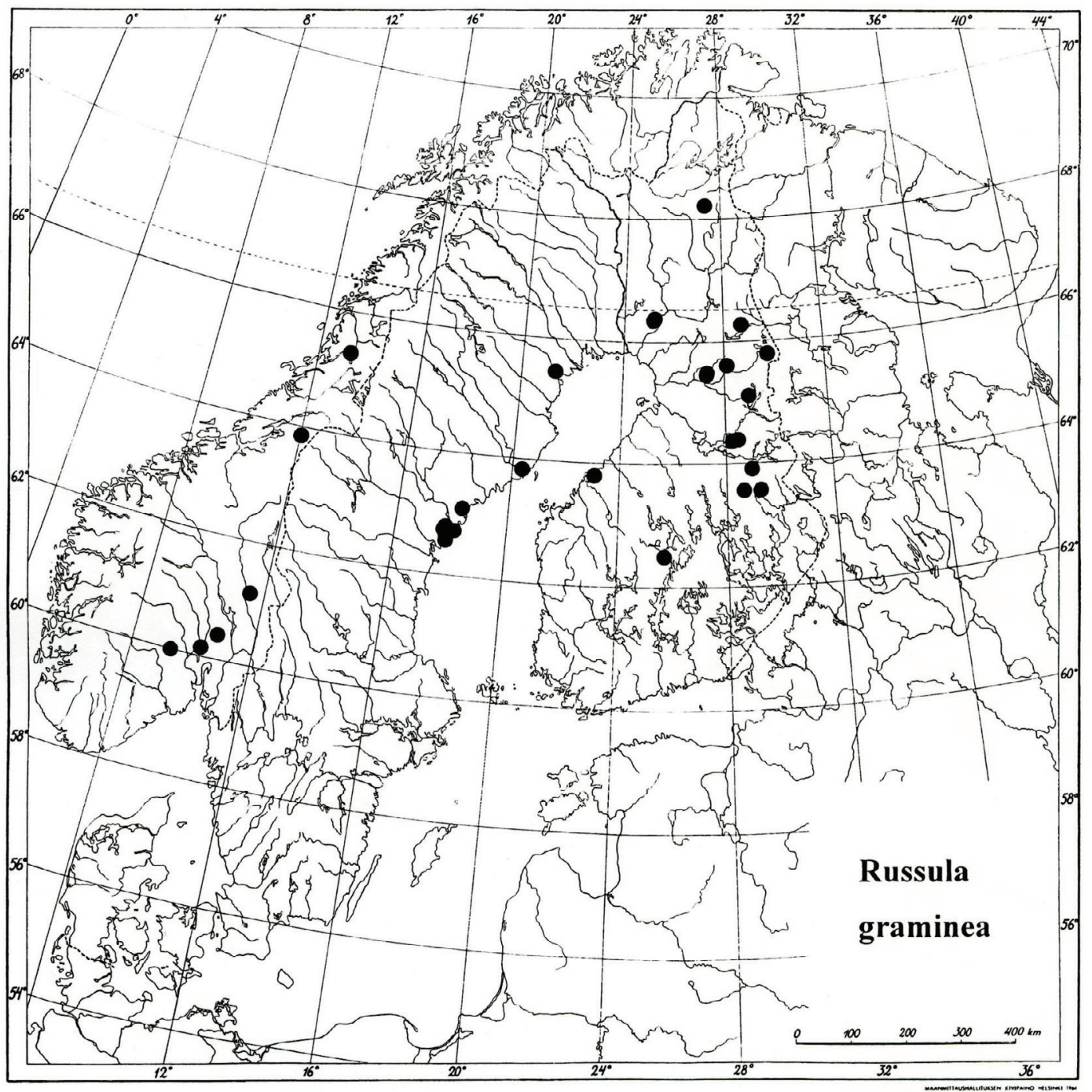

Fig. 4. Distribution of Russula graminea in Fennoscandia, according the material examined.

Vaccinium myrtillus, Gymnocarpium dryopteris, Geranium sylvaticum, Trientalis europaea, Maianthemum bifolium, Cornus suecica, Lycopodium annotinum, Rubus saxatilis, Melica nutans, Coeloglossum viride, Orthilia secunda and Pleurozium schreberi. Other fungi observed close to $R$. graminea include Cortinarius evernius (Fr.: Fr.) Fr., Inocybe bufonia Kokkonen \& Vauras, $I$. grammata Quél., Lactarius trivialis (Fr.: Fr.) Fr., Russula griseascens (Bon \& Gaugué) Marti and $R$. taigarum Ruots. \& Vauras. It grows as small groups as a fairly rare species.
In Fennoscandia the fruiting period of $R$. graminea starts in mid-July, reaches the maximum in mid-August - late August, and ceases in mid-September.

Specimens studied: FINLAND. Pohjois-Häme. Laukaa, near Hitonhauta, 8.IX.2002 Toivonen 2036 (TUR). Pohjois-Karjala. Nurmes, Tervavaara, 13.VIII.2005 Kokkonen \& Vauras 23050F (TUR-A, C, M, TU, GenBank no. KC164351), 22.VIII.2007 Kokkonen \& Vauras 24940 (TUR-A), 16.VIII.2008 Kokkonen \& Vauras $26121 F$ (TUR-A); Rautavaara, Pumpulikirkko Nature Reserve, 15.IX.2008 Kokkonen 317/08 (TUR). Keski- 
Pohjanmaa. Kokkola, N part of town, near Rödsöntie, VIII.1981 Storbacka (OULU), 28.VIII.1985 Storbacka 85224 (TUR-A), 1.9.1986 Storbacka 86210 (TUR-A). Kainuu. Paltamo, Saukkovaara, 24.VIII.2011 Ruotsalainen \& Vauras $28360 F$ (TUR-A); Puolanka, Suolijärvi, Paljakka, Honka-Jylkky, SE slope, 25.VIII.1977 E. Ohenoja (OULU); Ristijärvi, Saukkovaara, 18.VIII.2010 Ruotsalainen (TUR-A, C); Sotkamo, Hiidenportti National Park, 6.IX.2001 Kytövuori \& Toivonen 1021 (TUR), 20.VIII.2002 Kokkonen \& Vauras 19333 (TUR-A); Suomussalmi, Julman Huuru, 27.VIII.2011 Ruotsalainen (no specimen, old fruit bodies seen). Oulun Pohjanmaa. Pudasjärvi, Lehtovaara, Saarivaara, W slope, 30.VIII.1987 M. Ohenoja (OULU), Naamanka, Pärjä, Nälkövaara, SW slope, 22.VIII.1997 M. Ohenoja (OULU, H, TUR). Perä-Pohjanmaa. Rovaniemi, Pisavaara, 18.VIII.1957 Tuomikoski (H), Louevaara, 20.VIII.2011 Kekki 201 (TUR). Koillismaa. Kuusamo, Hiltunen, Iivaara, E slope, 31.VIII.1977 Korhonen 1970 \& Tuomikoski (H), Ulvinen (OULU), 19.VIII.1997 Ruotsalainen 4372F (holotype), 1.IX.2005 Marstad (O), Ruotsalainen \& Vauras 23358 (TUR-A), 29.VIII.2007 Ruotsalainen \& Vauras $25066 F$ (TUR-A, JYV, GenBank no. KC164352); Posio, Riisitunturi National Park, Noukavaara, 15.VIII.2010 Calledda, Tasselli, Carbone \& Boerio (TUR-A); Taivalkoski, Lomavaara, 11.VIII.1974 Huovinen (OULU). Sompion Lappi. Sodankylä, NE of Tankajoki and Tankapirtti house, 13.VIII.1995 Kytövuori 95-262 (H). NORWAY. Buskerud. Ringerike, Blekkentjern, 16.VIII.2006 Seem \& Nilsen (O, TUR-A); Rollag, Minneskleiv, 9.VIII.2009 Braathen et al., PM 122-09 (O). Oppland. Gran, Gullenhaugen Nature Reserve,16.VIII.2010 E. Bendiksen 42/10, 43/10 (O). Hedmark. Åmot, Glomstad, 30.VIII.2002 Rørhus (O, TUR-A). Nord-Trøndelag. Steinkjer, E of Mokk, 9.IX.2008 Holien 78/08 (O, TUR-A, GenBank no. KC164353). Nordland. Grane, Holmvassdalen, 31.VIII.2010 K. Bendiksen, E. Bendiksen \& Brandrud 140/10 (O). SWEDEN. Ångermanland. Häggdånger, Torrom, Torromsberget, 26.VIII.1997 Nylén (H); Säbrå, Aspnäs, E side of Storvegsjön, Västersjälandsbodarna, 27.VIII.1997 von Bonsdorff $(\mathrm{H})$, Berge, Furuhultsåm, 10.VIII.1988 Unger (Herb. Hans Marklund), Billsta, ca $7 \mathrm{~km} \mathrm{~W}$ of Härnösand, E end of the lake Långsjö, 29.VIII.1997 Olofsson \& Höijer 2321 (TUR-A); Hemsö, Rävakullmon, 13.VIII.1980 Unger (Herb. Unger), Svartdalsberget, Gubbmyran, 4.VIII.1983 Unger (Herb. Unger), 14.VII.1984 Unger (S, Herb. Unger), 23.VII.1984 Unger (photograph only, TUR-A), 12.VIII.1985 Unger 85/39 (TUR-A), Olsmyran, 7.VIII.1995 Unger (Herb. Unger); Vibyggerå, Docksta, E side of Skuleberget, 20.VIII.1974 Kytövuori 5044 (H). Västerbotten. Umeå, Gimonäs, 6.IX.1981 Persson (UPS). Norrbotten. Piteå, Pålberget, 21.VIII.1983 Öster (UPS).

\section{Discussion}

Russula graminea is an easy species to recognize already in the forest. It is a large Russula, like $R$. paludosa Britzelm. but with bright green pileus and white stipe. However, some features are fairly variable, like taste and spore print colour. Rarely the pileus of $R$. graminea can attain wine-red colours. This has been documented by Hans-Gunnar Unger in Sweden, Ångermanland. In our material from Finland this feature has not been seen. But we observed once abundant red colour at margin of pileus of Russula olivina. In good weather situations fruit bodies of Russula can have more intensive colours that usually. It seems that red colour on green-capped species of Russula can occur under such conditions.

A species with fairly similar, but not so bright, pileus colour is $R$. olivina. Sometimes also $R$. olivobrunnea can have green colours on pileus. These two mild species grow also with Picea abies, but they have more slender fruit bodies and large spores with isolated warts. A third species, growing mainly with Picea abies, is $R$. postiana. This mild species has a matt pileus and stipe, lamellae are yellow to orange, spore deposit is yellow (IVd), and often stipe base has a smell of iodoform. A species closely related to R. postiana, R. parolivascens Bidaud \& MoënneLocc., has also been found in SW Finland (Varsinais-Suomi, Parainen, M. \& P. Heinonen 288-90 (TUR, det. J. Ruotsalainen 2008).

$R$. aeruginea Lindblad is a common species growing mainly with Betula. However, we have seen also groups of it in forests of Picea abies. $R$. aeruginea has not so bright green pileus as $R$. graminea. It has paler spores in mass. Further, spores are smaller, more oblong and with an inamyloid plage, and dermatocystidia are aseptate.

$R$. luteoviridans C.Martin is a species not well understood. Sarnari (1998) has the name as a synonym (with question mark) under $R$. cuprea Krombh. On the other hand, $R$. luteoviridans C.Martin ss. Blum, with its mild taste and encrusted primordial hyphae, is a species of section Polychromae, subsection Integroidinae (Romagnesi 1967, Einhellinger 1985, Aicher 1996).

The ITS sequences of all the three collections of $R$. graminea studied were identical. In the comparison to Genbank, no close ITS sequences of possible sister species were found using BLAST (differing by less than 20 evolutionary events). As a fairly rare species, growing in older forests of Picea abies, $R$. graminea has been classified as a Near Threathened (NT) species in Finland (Bonsdorff et al. 2010). 
Acknowledgements: We began the manuscript of the new species Russula graminea with HansGunnar Unger $\dagger$. We appreciate his contribution and dedicate this enigmatic species to his memory. Curators of herbaria $\mathrm{H}, \mathrm{O}, \mathrm{OULU}, \mathrm{S}$ and UPS are gratefully acknowledged for arranging loans. We thank all friends for sending their specimens to us. Federico Calledda kindly gave us permission to use his beautiful photograph of $R$. graminea for the article, and Mauro Sarnari sent us important literature. This work was supported by the Ministry of Environment, Finland (YM38/5512/2009). Ernest Emmett is warmly thanked for improving the English.

\section{References}

Aicher, A. 1996: Regensburger Pilzflora 6: Täublinge (Russula, Russulaceae). - Regensburger Mykol. Schriften 7: 105-202.

Bonsdorff, T.von, Haikonen, V., Huhtinen, S., Kaukonen, M., Kirsi, M., Kosonen, L., Kytövuori, I., Ohenoja, E., Paalamo, P., Salo, P. \& Vauras, J. 2010: Agaricoid and Boletoid fungi. In: Rassi, P., Hyvärinen, E., Juslén, A. \& Mannerkoski, I. (eds.). The 2010 Red List of Finnish Species: 233-248. Ympäristöministeriö \& Suomen ympäristökeskus, Helsinki.

Einhellinger, A. 1985: Die Gattung Russula in Bayern. - Hoppea, Denkschriften Regensburgischen Botanischen Gesellschaft 43: 5-286.

Gardes, M. \& Bruns, T.D. 1993: ITS primers with enhanced specifity for basidiomycetes. Application to the identification of mycorrhizae and rusts. - Molecular Ecology 2: 113-118. doi:10.1111/j.1365294X.1993.tb00005.x.
Knudsen, H., Ruotsalainen, J. \& Vauras, J. 2012: Russula Pers. - In: Knudsen, H. \& Vesterholt, J. (eds.), Funga Nordica. Agaricoid, boletoid, clavarioid, cyphelloid and gastroid genera: 144-186. Nordsvamp, Copenhagen.

Küppers, H. 1981: DuMont's Farben-Atlas. $2^{\text {nd }}$ ed. 163 pp. DuMont Buchverlag, Köln.

Marstad, P. 2004: Kremler i Norden. - 70 pp. Per Marstad, Tønsberg.

Niskanen, T., Kytövuori, I., Liimatainen, K. 2009: Cortinarius sect. Brunnei (Basidiomycota, Agaricales) in North Europe. - Mycological Research 113: 182-206. doi:10.1016/j.mycres.2008.10.006.

Romagnesi, H. 1967: Les Russules d'Europe et d'Afrique du Nord. - 998 pp. Bordas, Paris.

Ruotsalainen, J. \& Vauras, J. 1990: Finnish records of the genus Russula. The new species R. olivina and R. taigarum. - Karstenia 30: 15-26.

Ruotsalainen, J. \& Vauras, J. 1991: Lehtoviinihapero (Russula pubescens) Suomessa. - Sienilehti 43: 3942.

Ruotsalainen, J. \& Vauras, J. 1994: Novelties in Russula: R. olivobrunnea, R. intermedia and R. groenlandica. Karstenia 34: 21-34.

Ruotsalainen, J. \& Vauras, J. 1995: Polkuhapero, Russula violaceoincarnata, muuntelun mestari. - Sienilehti 47: 47-53.

Ruotsalainen, J., Sarnari, M. \& Vauras, J. 1997: Russula fulvograminea, una nuova specie in Fennoscandia. Rivista di Micologia 40: 99-107.

Sarnari, M. 1998: Monographia illustrate del Genere Russula in Europa. - 799 pp. A.M.B. Fondazione Centro Studi Micologici, Vicenza.

White, T.J., Bruns, T., Lee, S. \& Taylor, J. 1990: Amplification and direct sequencing of fungal ribosomal RNA genes for phylogenetics. In: Michael A.J., Gelfand D.H., Sninsky J.J. \& White T.J. (eds.), PCR protocols: a guide to the methods and applications: 315-322. Academic Press, New York. 